\title{
IDENTIFIKASI HAZARD DAN PERANCANGAN SISTEM INFORMASI KESELAMATAN DAN KESEHATAN KERJA DI UNIT AMONIAK (Studi Kasus : PT. PETROKIMIA GRESIK)
}

\author{
Eko Nurmianto, Nurma Anita dan Apriani Nur Aulia \\ Jurusan Teknik Industri \\ Institut Teknologi Sepuluh Nopember Surabaya \\ Email : nurmi@sby.centrin.net.id
}

\section{ABSTRACT}

\begin{abstract}
Safety ergonomic is compulsory thing to be applied in every company to guarantee workers safety. To see how far safety ergonomic implemented, instead doing SMK3 audit, risk assessment approach method is other exemplary way by identifying the existing hazards and to measure how concern is the company in safety ergonomic subject.

PT. Petrokimia Gresik is one of chemical company known as fertilizer producer which had outstanding acknowledgement in safety ergonomic subject, one of them is zero accident award. The definition of zero accident here is the company has minimum level of high risk accident, not with the understanding that the company has no accident at all. In despite of that, risk assessment method is still needed in order to monitoring action.

Risk assessment is performed to produce a data that can expose areas where only a high hazards level exist, kind of hazards, and how to prevent and control the hazards. During this process, results are stored only to make an evaluation of the company, in this problem analysis, researcher will design an information system that will be a media repository and facilitate the users to know if there are hazards in a work unit
\end{abstract}

Keyword : Hazard, Risk Assessment, Information System, Ergonomic Safety

\section{PENDAHULUAN}

Keselamatan dan kesehatan kerja (K3) merupakan salah satu aspek perlindungan tenaga kerja dan sekaligus melindungi aset perusahaan atau industri. Keselamatan adalah pencegahan terjadinya kecelakaan untuk menghindari cedera bagi manusia atau kerusakan fasilitas kerja serta lingkungan kerja. Kecelakaan adalah suatu kejadian yang tidak direncanakan muncul yang mengakibatkan cedera atau kerusakan. Kesehatan adalah pencegahan terhadap penyakit yang mengganggu kondisi fisik dan mental manusia. Di dunia industri K3 adalah hal yang penting sehingga harus benar-benar diperhatikan, karena ini menyangkut kesehatan dan keselamatan dari manusia, baik itu pekerjanya sendiri maupun masyarakat di sekitarnya. Kecelakaan kerja dapat menimbulkan korban jiwa maupun kerugian materi bagi pekerja dan pengusaha, tetapi juga dapat mengganggu proses produksi secara menyeluruh, merusak lingkungan yang pada akhirnya akan berdampak pada masyarakat luas, oleh karenanya program keselamatan kerja dan pencegahan 112 kecelakaan harus menjadi perhatian utama karena masalah keselamatan dan kesehatan adalah kepentingan pengusaha, pekerja dan pemerintah di seluruh dunia.

Hal diatas sesuai dengan Undang-Undang No 1 Tahun 1970 tentang Keselamatan Kerja yaitu "Setiap tenaga kerja berhak mendapat perlindungan atas keselamatan dalam melakukan pekerjaan dan setiap orang yang berada di tempat kerja perlu terjamin pula keselamatannya serta setiap sumber produksi perlu dipakai dan dipergunakan secara aman dan efisien sehingga proses produksi berjalan lancar".

Pada dasarnya kecelakaan dapat terjadi dimanapun dan kapan pun, jika dalam industri kecelakan diakibatkan oleh unsafe action, unsafe behaviour dan unsafe condition. Faktor-faktor penyebab tersebut dapat diminimalis jika pihak perusahaan benar-benar menerapkan Sistem Manajemen Keselamatan dan Kesehatan Kerja (SMK3).

PT. Petrokimia Gresik adalah perusahaan yang mendapat penghargaan Zero Accident, namun 
dibalik penghargaan tersebut pihak perusahaan masih saja menghadapi masalah terkait dengan bidang K3 misalnya budaya disiplin K3 (unsafe behaviour), unsafe condition terkait dengan proses produksi dan lain sebagainya. Pihak perusahaan sudah melakukan beberapa tindakan untuk meminimalis kondisi demikian. Salah satunya adalah dengan melakukan hazard analysis dengan mendifinisikan hazard (bahaya) dan risk (resiko). Dari proses ini akan dapat diketahui prioritas resiko untuk masing-masing unit produksi sehingga dapat dilakukan tindakan preventive untuk menekan angka kecelakaan kerja.

Produk dari PT. Petrokimia Gresik diproses di 3 bagian pabrik, Pabrik I, Pabrik II dan Pabrik III yang setiap bagiannya memiliki beberapa unit produksi. Amoniak adalah salah satu unit produksi di Pabrik I. Jika dikaitkan dengan Keselamatan dan Kesehatan Kerja, unit Amoniak adalah unit yang memiliki potensi bahaya tinggi karena proses berjalan pada tekanan tinggi, suhi tinggi dan kecepatan tinggi, walaupun di unit ini jumlah pekerja sedikit karena semua proses terkendali secara otomatis.

Analisa permasalahan ini bertujuan untuk mengidentifikasi hazard pada unit Amoniak dan memperbaiki pencegahan dan penanggulangannya serta merancang sistem informasi K3 untuk unit Amoniak, dengan batasan penelitian hanya dilakukan di unit Amoniak.

\section{TINJAUAN PUSTAKA}

\section{Definisi K3 \& Hazard}

Kesehatan dan Keselamatan Kerja merupakan suatu konsep yang berupaya untuk menjamin kelestarian lingkungan kerja dan tenaga kerja secara jasmani dan rohani. Sedangkan tujuan dari penerapan K3 adalah untuk mencegah atau mengurangi resiko kecelakaan dan penyakit yang disebabkan oleh pekerjaan atau lingkungan kerja. Kesehatan kerja bertujuan untuk menjunjung tinggi nilai kesehatan tenaga kerja. Tujuan ini dapat dicapai dengan melakukan pencegahan maupun pemberantasan penyakit akibat kerja.

Ashfal (1999) dan Nurmianto dkk (2006) menyatakan bahwa hazards melibatkan resiko atau kesempatan, yang berkaitan dengan elemen-elemen yangtidakdiketahui(unknown). SedangkanHammer (1989) dan Nurmianto (2004) mendefinisikan hazards sebagai kondisi yang potensial untuk menyebabkan injury terhadap personel, kerusakan peralatan atau struktur bangunan, kerugian material, atau mengurangi kemampuan untuk melakukan suatu fungsi yang telah ditetapkan.

\section{Peraturan dan Perundang-undangan Keselamatan dan Kesehatan Kerja}

Tata urutan peraturan perundangan yang berlaku tentang Keselamatan dan Kesehatan Kerja adalah UUD 1945, TAP MPR, Undang-undang, serta Peraturan Pemerintah Pengganti Undangundang Peraturan Pemerintah, Menteri serta instruksi menteri. Berikut ini beberapa peraturan dan perundang-undangan K3 yang disusun sesuai dengan hirarki disektor ketenagakerjaan :

1. Undang-undang Dasar Negara Republik Indonesia 1945 pasal 27 ayat 2

2. UU no. 1/1970 tentang Keselamatan Kerja. Undang-undang yang disahkan pada 12 Januari 1970 ini mengatur tentang kesehatan \& keselamatan kerja bagi tenaga kerja di wilayah Republik Indonesia.

3. UU no. 14/1969 tentang Tenaga Kerja

\section{Risk Assessment}

Menurut Bakornas tahun 2007, definisi resiko adalah besarnya kerugian ( jiwa, kerusakan dan kerugian ekonomi ) yang disebabkan oleh bahaya tertentu di suatu daerah tertentu dan waktu tertentu.

Langkah awal yang dilakukan adalah mengidentifikasi bahaya yang mungkin terjadi. Setiap bahaya yang sudah diidentifikasi harus dinilai resikonya.Penilaian resiko terutama ditujukan untuk menyusun prioritas penanganan bahaya yang sudah diidentifikasi. Risk assessment akan bermanfaat jika hasil resiko yang telah teridentifikasi dan diprioritaskan tersebut ditindaklanjuti dengan cara mengelola(mengendalikan/memperlakukan)resiko tersebut dengan baik. Manajemen mengelola resiko tersebut dengan cara mengurangi kemungkinan terjadinya resiko, mengurangi dampak/pengaruh yang ditimbulkannya, mentransfer seluruhnya atau sebagian resiko, atau menghindari resiko. Tujuan akhirnya adalah resiko yang ada dapat berkurang pada tingkat yang dapat ditoleransi oleh manajemen. Dengan demikian secara keseluruhan risk assessment akan mendukungpelaksanaan manajemen resiko yang baik pada suatu organisasi (Susanto, 2008).

\section{Bahasa Pemograman}

Microsoft Access for Windows adalah aplikasi perangkat manajemen database yang luwes yang bisa digunakan untuk mengurutkan, menyeleksi 
dan mengatur informasi penting yang diperlukan. Kemudahan penggunaannya menjadikan software ini banyak digunakan baik oleh pengguna komputer yang baru mengenal database maupun yang sudah berpengalaman dengan database. Database adalah susunan data-data yang teratur urutannya.

\section{METODE}

Penelitian dilakukan dengan mengumpulkan data-data seperti, profil perusahaan, proses pembuatan Amoniak, data kecelakaan kerja, MSDS (Material Safety Data Sheet), cara pengendalian dan pencegahan hazard dari proses Amoniak. Setelah itu dilakukan mapping hazard dengan identifikasi terhadap hazard (bahaya) dan resiko yang ditimbulkan lalu ditentukan cara pencegahan dan penanggulangan berdasarkan masing-masing bahaya. Lalu dilakukan penilaian kuantitatif terhadap nilai dampak dan peluang untuk masingmasing bahaya sehingga didapatkan nilai resiko serta dapat ditentukan risk priority. Setelah itu dibuat suatu perancangan sistem informasi K3 di unit Amoniak berdasarkan risk assessment tersebut.

\section{HASIL DAN PEMBAHASAN}

\section{Proses Amoniak}

Amoniak merupakan salah satu produk yang dihasilkan di Pabrik I PT. Petrokimia Gresik. Kapasitas produksi Amoniak 445.000ton/ tahun. Fungsi di PT. Petrokimian Gresik adalah sebagai nahan baku pabrik pupuk ZA, Urea dan PHONSKA. Pabrik Amoniak PT.Petrokimia Gresik menggunakan proses low energy dari " $M W$ Kellog". Bahan baku yang digunakan adalah gas alam dan $\mathrm{N}_{2}$. Gas alam yang digunakan diambil dari daerah Pagerungan, Sumenep, Madura.

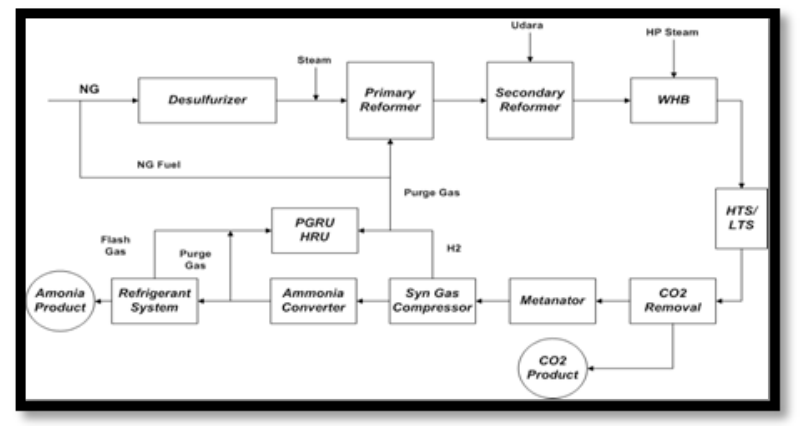

Gambar 1. Proses Amoniak

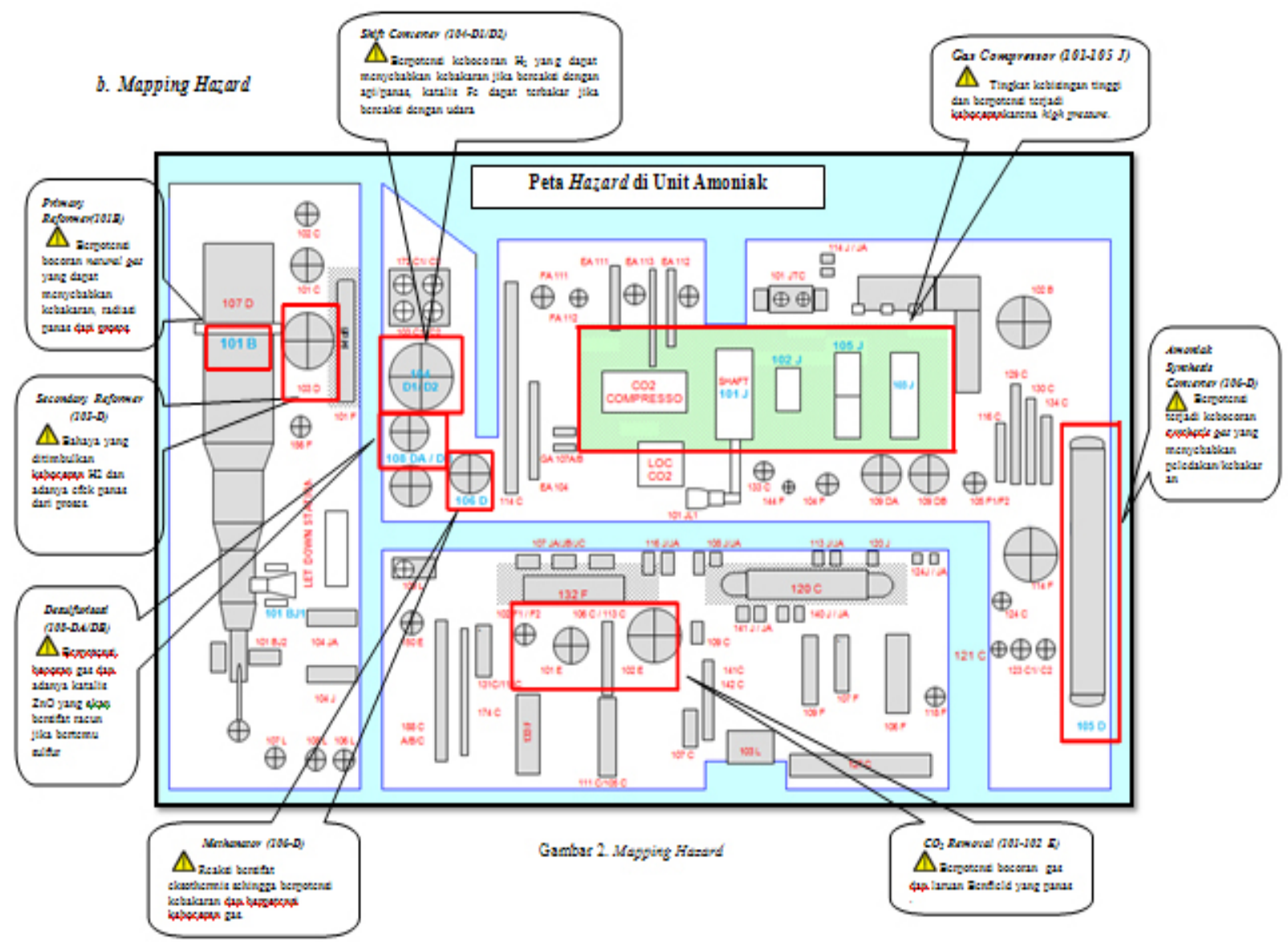




\section{Perangkingan Resiko}

PT. Petrokimia Gresik telah melakukan manajemen resiko dengan ketentuan yang dilakukan adalah menghitung tingkat resiko yang ada. Besarnya tingkat resiko diperoleh dari hasil perkalian antara dampak resiko dan peluang resiko yaitu:

\section{Dampak Resiko (D)}

Merupakan ukuran resiko atau besarnya pengaruh terjadinya resiko terhadap tenaga kerja/manusia. Skala pengukuran dampak didasarkan atas kriteria pada tabel berikut :

Tabel 1 Skala Kriteria Dampak Resiko

\begin{tabular}{|c|c|c|c|}
\hline Skala & Kriteria & \multicolumn{2}{c|}{ Dampak } \\
\hline 1 & Insignificant & Tidak insignificant terhadap tenaga kerja/ manusia & Tidak ada cidera \\
\hline 2 & Minor & Kecil terhadap tenaga kerja/manusiaa & Cidera dan masih bisa bekerja \\
\hline 3 & Moderate & Sedang terhadap tenaga kerja/manusia & Cidera dan tidak bisa bekerja \\
\hline 4 & Major & Besar terhadap tenaga kerja/manusia & Cacat tubuh \\
\hline 5 & Catastropic & $\begin{array}{c}\text { Significant/sangat besar terhadap tenaga kerja/ } \\
\text { manusia }\end{array}$ & Meninggal dunia \\
\hline
\end{tabular}

(Sumber : Biro Manajemen Resiko PT. Petrokimia Gresik, Panduan pengisian formulir Identifikasi Resiko

\section{Peluang Resiko (P)}

Merupakan besarnya kemungkinan atau frekuensi terjadinya resiko tersebut dalam setiap kegiatan yang dilaksanakan. Skala pengukuran peluang resiko didasarkan atas kriteria pada tabel berikut :

Tabel 2 Skala Pengukuran Peluang Resiko

\begin{tabular}{|c|c|c|c|}
\hline & Kriteria & Peluang & Resiko \\
\hline 1 & Rare & Sangat kecl/jarang & 0-1 kali terjadi setiap tahun $(0-20 \%)$ \\
\hline 2 & Unlikely & Kecil/cukup sekali-kali & $\begin{array}{c}>1-2 \text { kali terjadi setiap tahun }\left(>20 \% 0^{-}\right. \\
40 \%)\end{array}$ \\
\hline 3 & & Dapat terjadi/sedang & $\begin{array}{c}>2-4 \text { kali terjadi setiap tahun }(>40 \%- \\
60 \%)\end{array}$ \\
\hline 4 & Likely & Cenderung pasti/sering terjadinya & $\begin{array}{l}>4-6 \text { kali terjadi setiap tahun }(>60 \%- \\
80 \%)\end{array}$ \\
\hline 5 & Certain & Hampir selalu terjadi/pasti terjadi & $\begin{array}{l}>6 \text { kali terjadi setiap tahun }\left(>80 \% 0^{-}\right. \\
100 \%)\end{array}$ \\
\hline
\end{tabular}

(Sumber : Biro Manajemen Resiko PT. Petrokimia Gresik, Panduan Pengisian Formulir Identifikasi

Resiko K3 dan Penyakit Akibat Kerja, 2008)

\section{Penentuan Tingkat Resiko}

Penentuan tingkat resiko adalah dengan mengkombinasikan perhitungan dari dampak resiko dan peluang resiko.

\section{Resiko $=$ Dampak (D) X Peluang (P)}

Setelah didapatkan nilai resikonya kemudian dapat diketahui tingkat kategori resikonya. Kategori resiko tersebut sebagai berikut :

$\Rightarrow$ Resiko rendah jika nilai resiko $\leq 4$

$\Rightarrow$ Resiko sedang jika nilai resiko $>4-12$

$\Rightarrow$ Resiko tinggi jika nilai resiko $>12-25$

Selain itu dari besar resiko dapat ditentukan nilai prioritas. Prioritas merupakan perangkingan terhadap nilai resiko dengan range nilai mulai dari 1 untuk nilai resiko terbesar dan selanjutnya.

Perangkingan resiko ini dimulai dengan mendefinisikan hazard dan sumbernya lalu mendefinisikan resiko, akibat dan selanjutnya menentukan nilai peluang dan dampak. Nilai ini diperoleh dari hasil brainstorming dengan pihak produksi.

Dibawah ini adalah tabel perangkingan hazard yang dilakukan untuk Pabrik I Unit Amoniak PT. Petrokimia Gresik : 


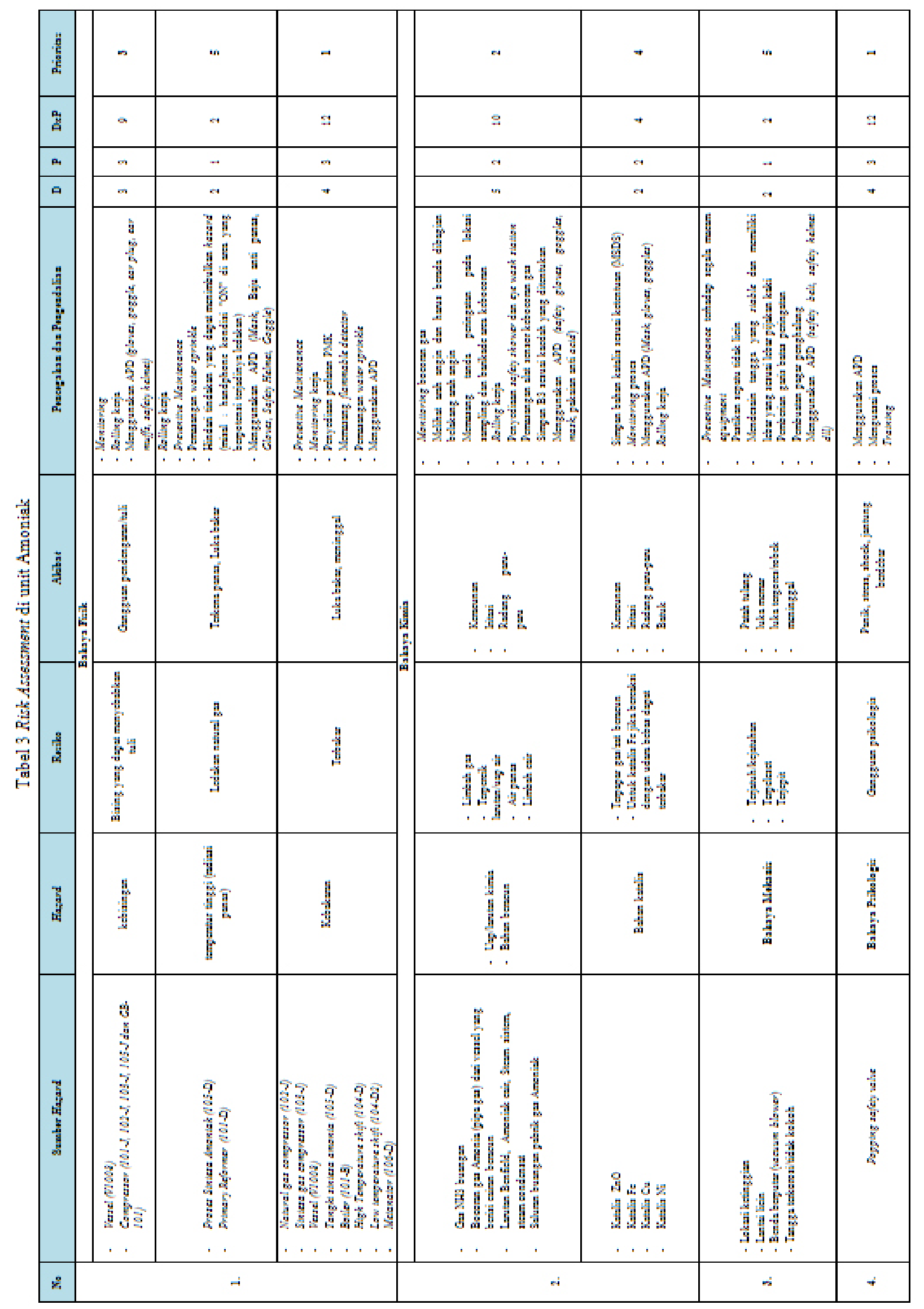




\section{ANALISIS DAN HASIL PENGOLAHAN DATA}

\section{a. Analisis Pencegahan dan Pengendalian Resiko}

Tindakan pencegahan dan pengendalian dilakukan untuk mengurangi potensi bahaya. Untuk menentukan pencegahan dan pengendalian hazard terdapat hirarki pencegahan dan pengendalian. Ada 5 tahapan hirarki yaitu Eliminasi, Substitusi, Rekayasa Engineering, Pengendalian Administratif dan Alat Pelindung Diri (lihat Gambar 2). Pencegahan dan pengendalian yang ada di Tabel 3 adalah aplikasi dari hirarki tersebut.

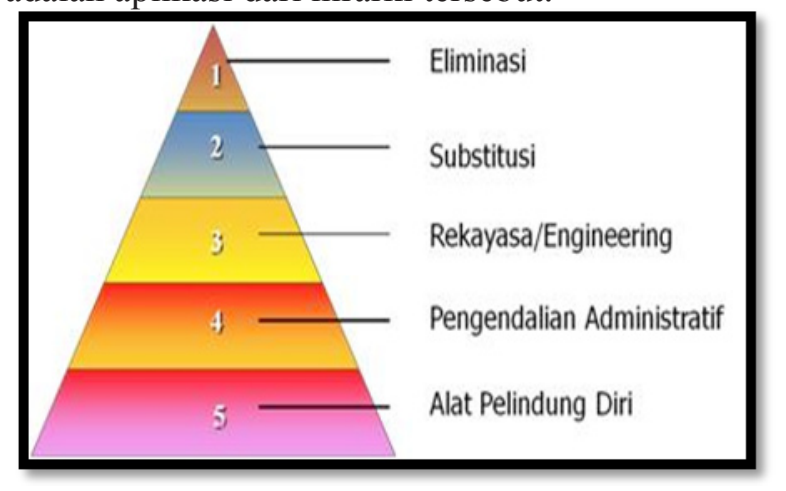

Gambar 2 Hirarki pengendalian

Pencegahan dan pengendalian diberikan untuk masing-masing jenis bahaya (hazard). Untuk tingkat eliminasi dilakukan dengan menghilangkan bahan atau tahapan proses yang menimbulkan hazard. Sedangkan untuk tingkatan sustitusi dilakukan dengan mengganti misalnya mengganti proses menyapu yang dapat menimbulkan debu disubstitusi dengan proses vacuum sehingga dapat mengurangi debu. Untuk tingkatan eliminasi dan substitusi kurang bisa dilakukan karena setelah observasi ke lapangan yaitu di Unit Amoniak pencegahan dan pengendalian dengan metode eliminasi dan substitusi sedikit sulit untuk dilakukan karena berpengaruh langsung dengan proses.

Untuk tingkatan rekayasa teknik yaitu tindakan pengendalian dan pencegahan dengan memberikan alat tambahan dengan tujuan dapat mereduksi hazard, seperti contohnya dengan memasang flammable detector dan water springkle untuk daerah yang berpotensi kebakaran/ledakan, penyediaan safety shower dan eye wash untuk pekerja dengan tujuan ketika ada pekerja yang terpapar langsung dengan gas/cairan Amoniak dapat langsung disiram dengan air sesuai keterangan pada MSDS Amoniak (Material Safety Data Sheet). Tindakan pencegahan yang diusulkan adalah pemasangan alat sensor kebocoran gas sehingga dengan pemasangan alat tersebut dapat mengurangi potensi kebakaran karena kebocoran gas. Selain itu ada beberapa tindakan teknis yang harus dilakukan sebagai tindakan pencegahan dan pengendalian antara lain dengan pengadaan tanda peringatan pada daerahdaerah yang berpotensi bahaya.

Untukpengendalian padatingkatanAdministratif yaitu dengan melakukan tindakan Preventive Maintenance, melakukan program rolling kerja, pemberlakuan shift kerja, pengadaan program pelatihan untuk pekerja.

Terkaitdengan penggunaanAPD (Alat Pelindung Diri), walaupun di diagram hirarki penggunaan APD ada pada tingkatan bawah tapi bukan berarti tidak dierapkan ketika hirarki sebelumnya telah dilakukan. APD adalah peralatan yang mutlak digunakan terutama untuk unit ini adalah safety helmet, safety shoes, ear plug/ear muffs dan mask.

\section{b. Analisa Perangkingan Hazard}

Perangkingan hazard dilakukan untuk mengetahui hazard mana saja yang mempunyai tingat resiko paling tinggi hingga paling rendah. Proses ini merupakan bagian dari risk assessment. Ada beberapa tool yang dapat digunakan untuk menganalisa mengenai resiko antara lain FMEA (Failure Mode and Effect Analysis), RCA (Root Cause Analysis) dan FTA (Fault Tree Analysis). Ketiganya mempunyai karakteristik dan tahapan proses yang berbeda dalam mengidentifikasi resiko.

FMEA adalah tool yang mengidentifikasi kegagalan (kecelakaan/hazard) dari sebuah sistem dan akibat atas kegagalan tersebut. Dengan menggunakan tool ini dapat menilai suatu kegagalan sehingga dapat ditentukan cara penanggulangan dan pencegahan. Penilaian dilakukan dengan menentukan tingkat resiko dari suatu kegagalan. RCA adalah tool yang mengidentifikasi dasar dari sebuah permasalahan yang disebabkan oleh kegagalan. Jika melihat kondisi perusahaan jika digunakan tool RCA output yang didapat hanyalah penyebab dari kegagalan yang akan dijadikan dasar perbaikan tanpa bisa ditentukan kegagalan mana yang memiliki tingkat resiko paling tinggi hingga paling rendah. Sedangkan untuk FTA membutuhkan suatu nilai probabilitas kaitannya dengan waktu kegagalan. Nilai ini tidak dapat ditentukan secara subjektivitas oleh observer tetapi 
harus melewati proses brainstorming dengan pihak safety engineering dan bagian proses.

Karena karakteristik masing-masing tool tersebut FMEA dirasa lebih sesuai diterapkan untuk menganalisa permasalahan ini.Output dari sebuah risk assessment dengan menggunakan tool FMEA adalah dapat menentukan nilai peluang dan dampak terhadap bahaya yang telah diidentifikasikan. Dari nilai resiko dan dampak tersebut nantinya didapat resiko dari hasil perkalian nilai dampak dan peluang. Setelah nilai resiko didapat selanjutnya dilakukan penentuan nilai prioritas terhadap resiko tersebut. Dan dari hasil (seperti Tabel 5.5) didapatkan bahwa bahaya yang memiliki nilai resiko tertinggi adalah bahaya psikologi dan bahaya fisik (kebakaran). Bahaya kebisingan dan bahaya kimia (terpapar gas/ cairan Amoniak) memiliki nilai resiko yang tinggi pula, mengingat unit Amoniak adalah unit yang berpotensi terjadi ledakan/kebakaran karena proses yang terjadi di unit ini bertekanan tinggi, suhu tinggi dan dengan bahan baku berbahaya (Natural Gas).

\section{c. Pembuatan Progrm Sistem Informasi K3 di unit Amoniak}

$\Rightarrow$ Model Konseptual Entity

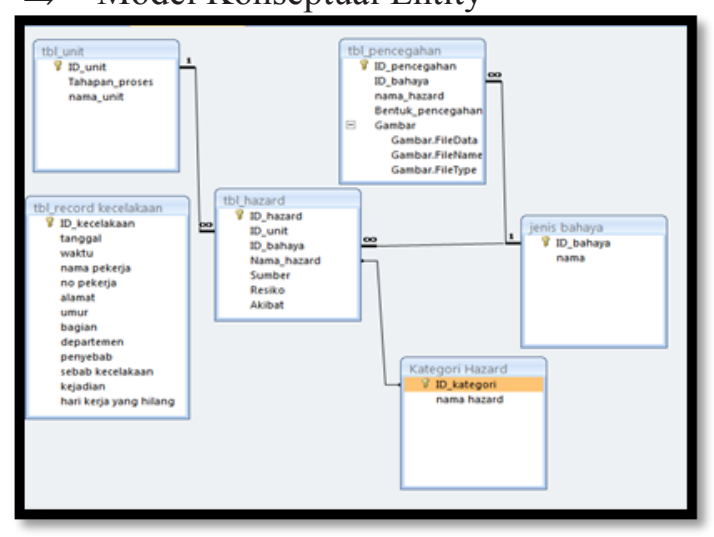

Gambar 3 Entity Relationship Diagram

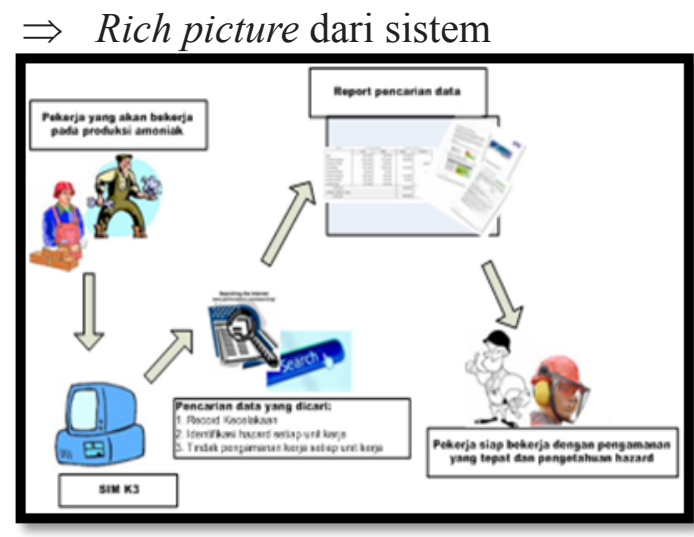

Gambar 4 Rich Picture Diagram
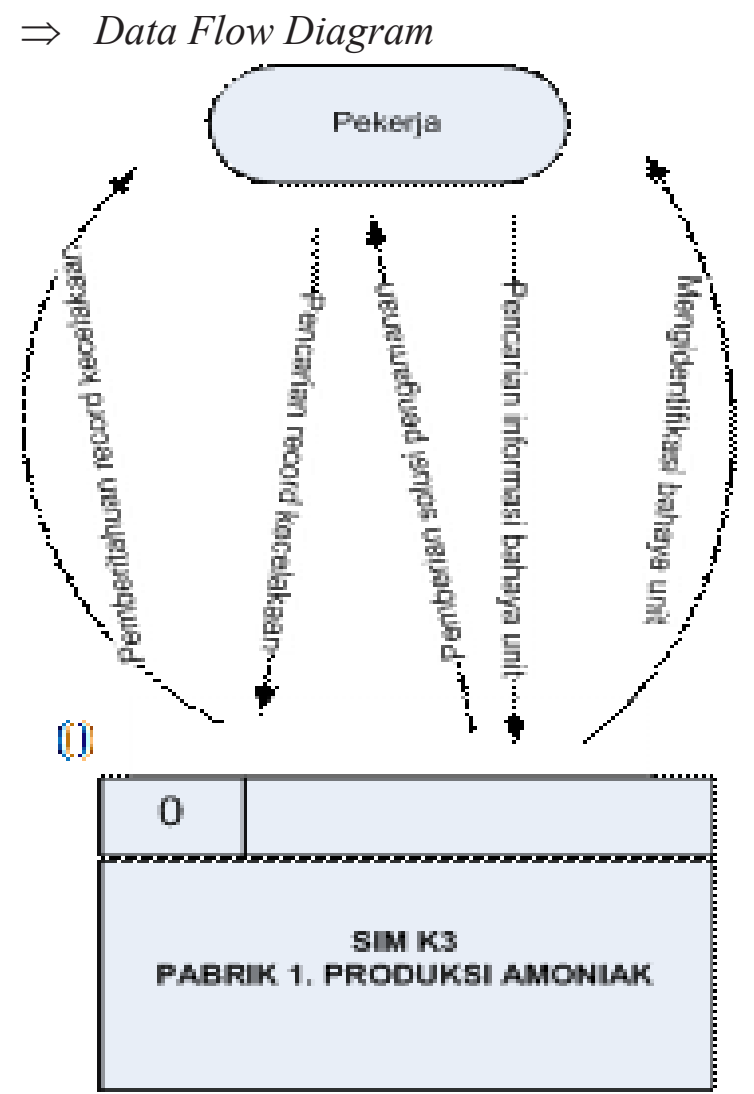

Gambar 5. DFD level 0

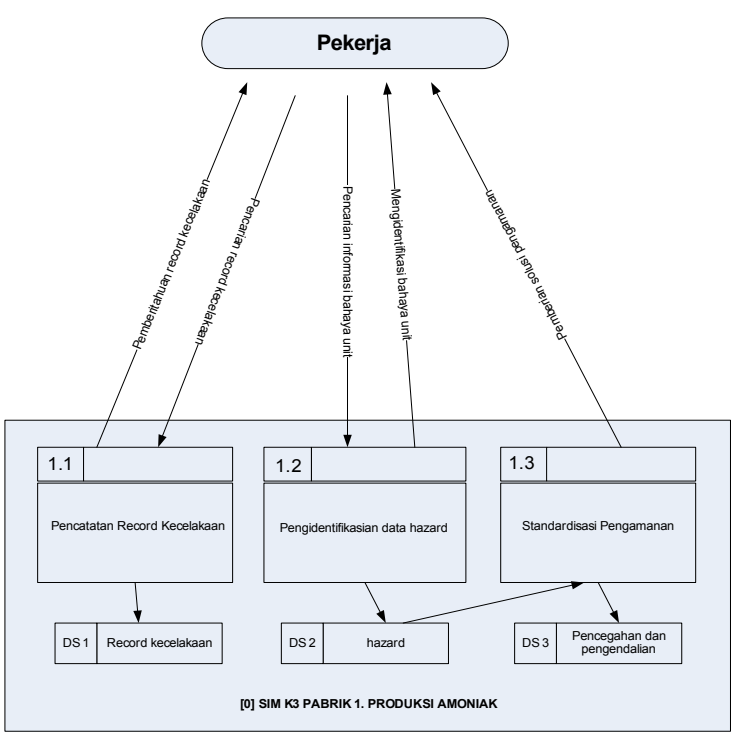

Gambar 6. DFD level 1

\section{d. Interface Sistem}

Sistem Informasi K3 ini memiliki 3 fitur utama yaitu pencarian data, record kecelakaan dan mapping hazard serta Alat Pelindung Diri (APD). Pada fitur pencarian data hazard berdasarkan dari unit kerja 
dan sumbur hazard. Fitur tersebut merupakan fitur pengidentifikasian hazard pada setiap unit kerja. Fitur record kecelakaan kerja akan menampilkan data kecelakaan kerja yang pernah terjadi pada pabrik I produksi Amoniak. Sedangkan untuk fitur mapping hazard akan menampilkan peta produksi amoniak serta pemetaan APD pada setiap unit kerja. Berikut ini adalah penjelasan untuk masng - masing fitur yang ada :

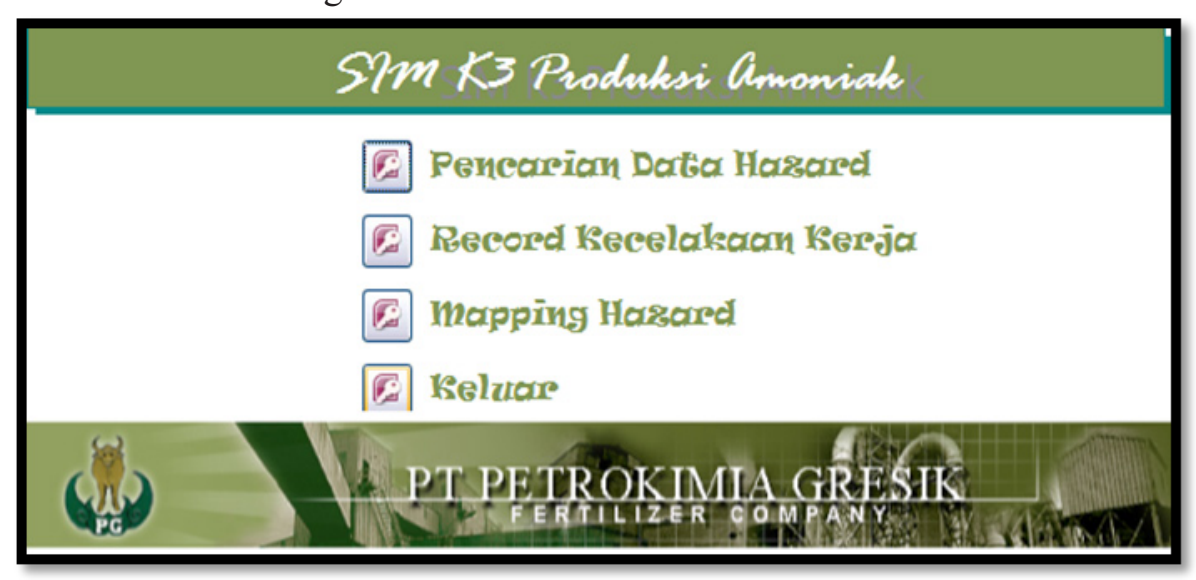

Gambar 7 Interface awal SIM K3

Pada home ketika masuk pada pilihan fitur pencarian data maka pekerja akan dihadapakan pada tampilan pencarian data hazard pada setiap unit. Ada dua pilihan pencarian data hazard yaitu berdasarkan unit kerja dan sumber hazard. Data yang harus diinputkan pada fitur ini juga disediakan pada pilihan menu, sehingga memudahkan pekerja. Berikut ini adalah tampilan menu pada fitur pencarian data :

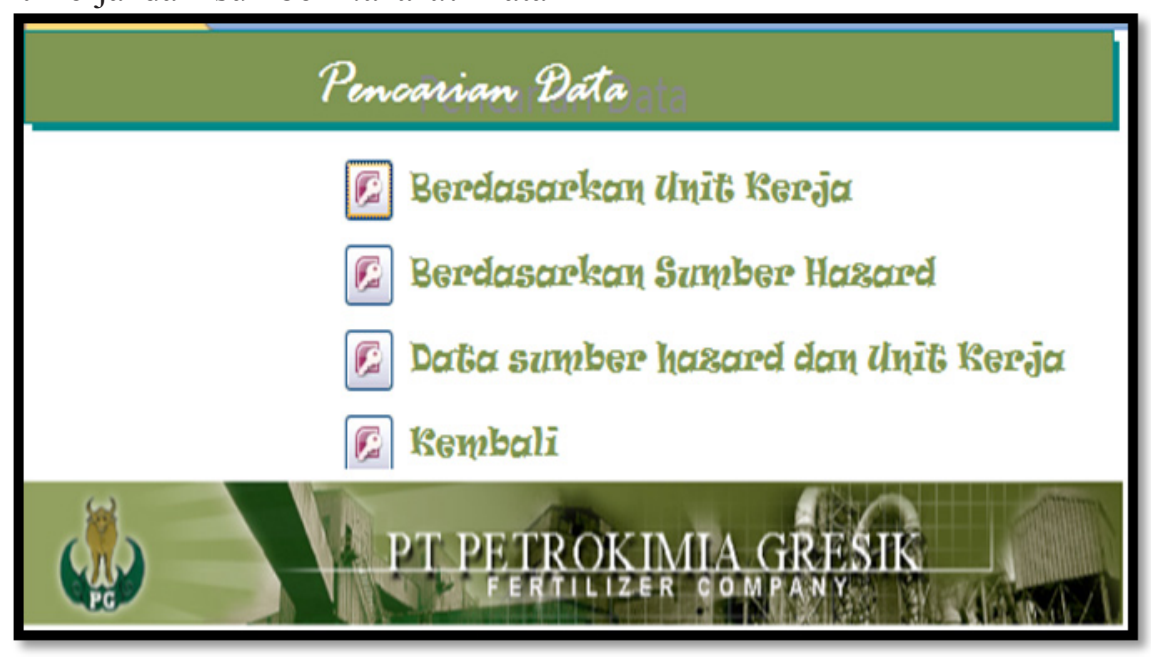

Gambar 8 Menu pilihan fitur pencarian data

Jika dipilih menu pencarian hazard berdasarkan unit kerja dan sumber hazard maka akan muncul tampilan seperti di bawah ini. Pengisian data harus sesuai dengan menu pilihan data sumber hazard dan unit kerja yang ada. Sedangkan report yang diberikan adalah berupa tampilan form yang berisis nama hazard, resiko, sumber hazard, akibat yang ditimbulkan dari hazard serta pengamanan yang harus digunakan ketika bekerja pada unit tersebut. Berikut ini adalah tampilan untuk search engine berdasarkan unit kerja. Untuk pencarian hazard berdasarkan sumber hazard tampilan vsama hanya berbeda pada inputan.

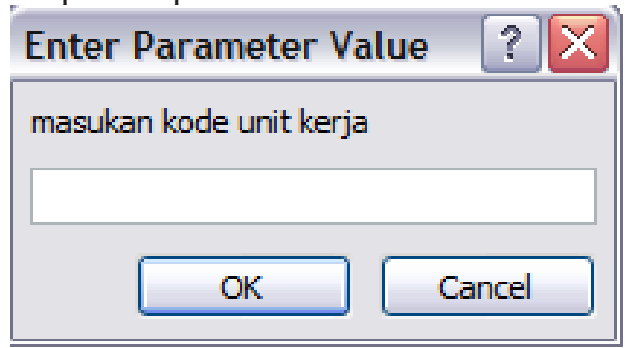

Gambar 9 Search Engine berdasarkan unit kerja 


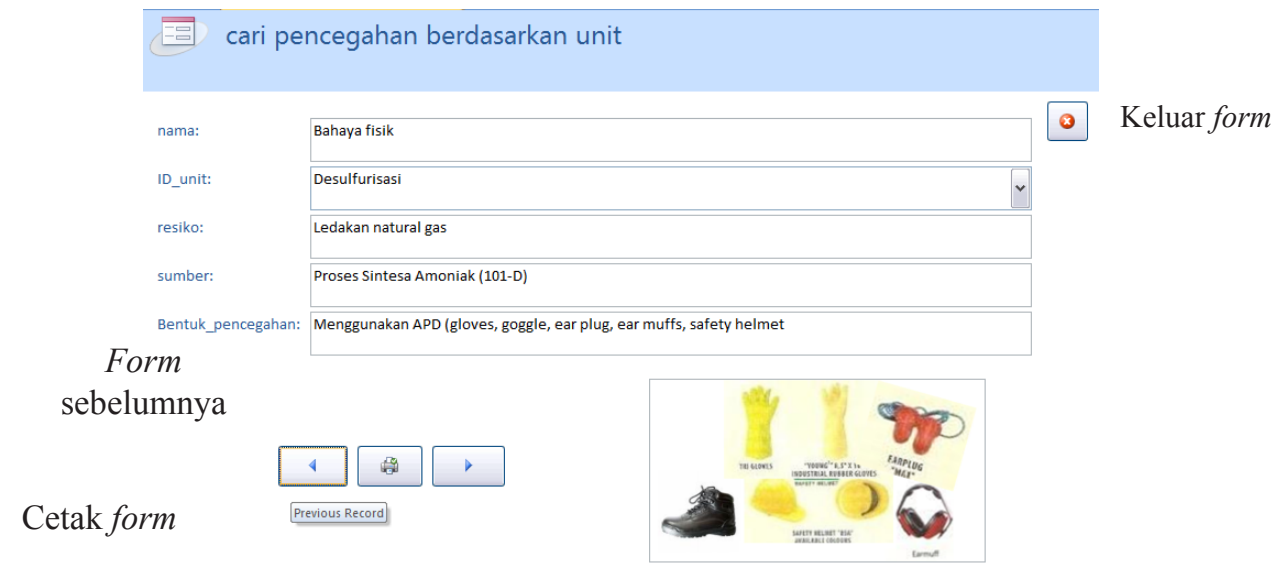

Gambar 10. Form hasil pencarian data

Pada fitur ini akan memuat rincian record kecelakaan yang pernah terjadi pada pabrik I unit produksi amoniak. Beberapa rincian ini antara lain identitas pekerja yang mengalami kecelakaan kerja, penyebab dari kecelakaan, serta bagaimana uraian kecelakaan kerja terjadi.

Pembuat database seperti ini untuk memperbaiki dari sistem database yang sudah ada. Pada sistem existing hanya berupa database excel dan dibukukan pada buku record kecelakaan kerja pada pabrik I. Sedangkan database dalam bentuk access lebih mudah pembacaan dan pencarian data yang diinginkan. Berikut ini adalah tampilan dari form record kecelakaan kerja :

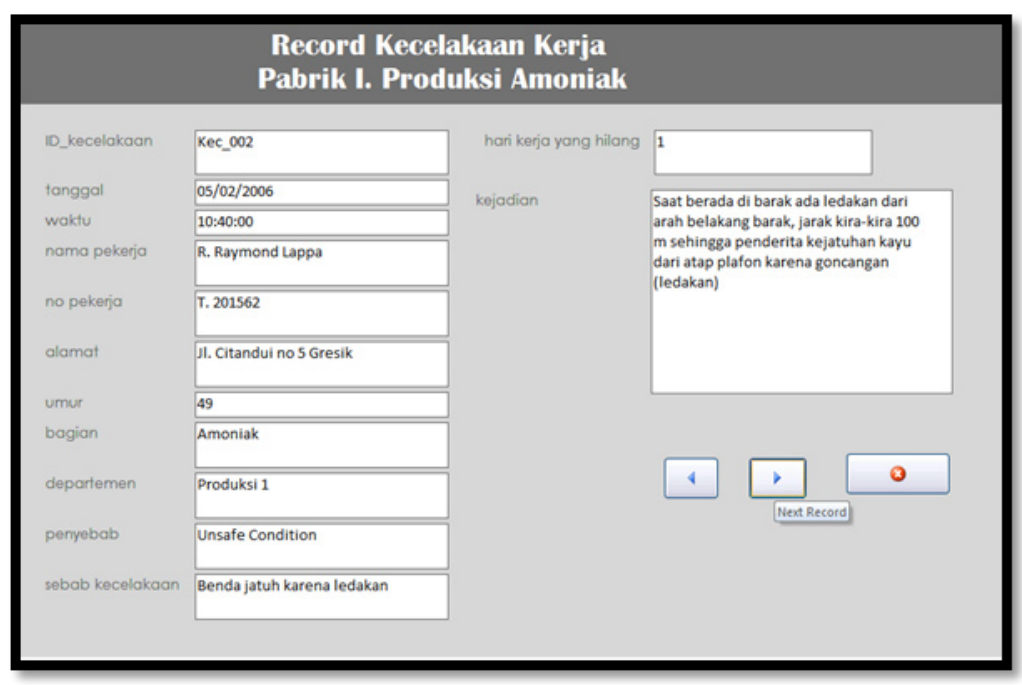

Gambar 11 Form record kecelakaan kerja

Pada fitur ini akan ditunjukkan pemetaan hazard pada pabrik I unit amoniak berdasarkan unit kerja yaitu uncit primary reformer, secondary reformer, gas compressor, shift conveter, desulfurisasi, metanator, $\mathrm{CO}_{2}$ removal,dan amoniak syntentic conventer. Unit Amoniak merupakan unit paling berbahaya pada pabrik I sehingga hazard harus diketahui oleh semua orang terutama pekerja yang melakukan pekerjaan pada unit amoniak. Hal ini telah dijelaskan dalam undang - undang K3 tahun 1970. Pembuatan fitur ini juga merujuk pada penjelasan tersebut dimana diharapkan dapat memberikan pengetahuan hazard kepada pekerja dan untuk perlindungan dan pengamanan pekerja.

Setelah diketahui hazard pada masing - masing unit kerja, perlu diketahui standar pengamanan yang perlu digunakan untuk mengurangi dan menghindari efek dari hazard yang ada. Oleh karena itu fitur mapping APD dibuat untuk memudahkan pekerja dalam pembacaan visual Alat Pelindung Diri ( APD ) yang diperlukan untuk pengamanan. 


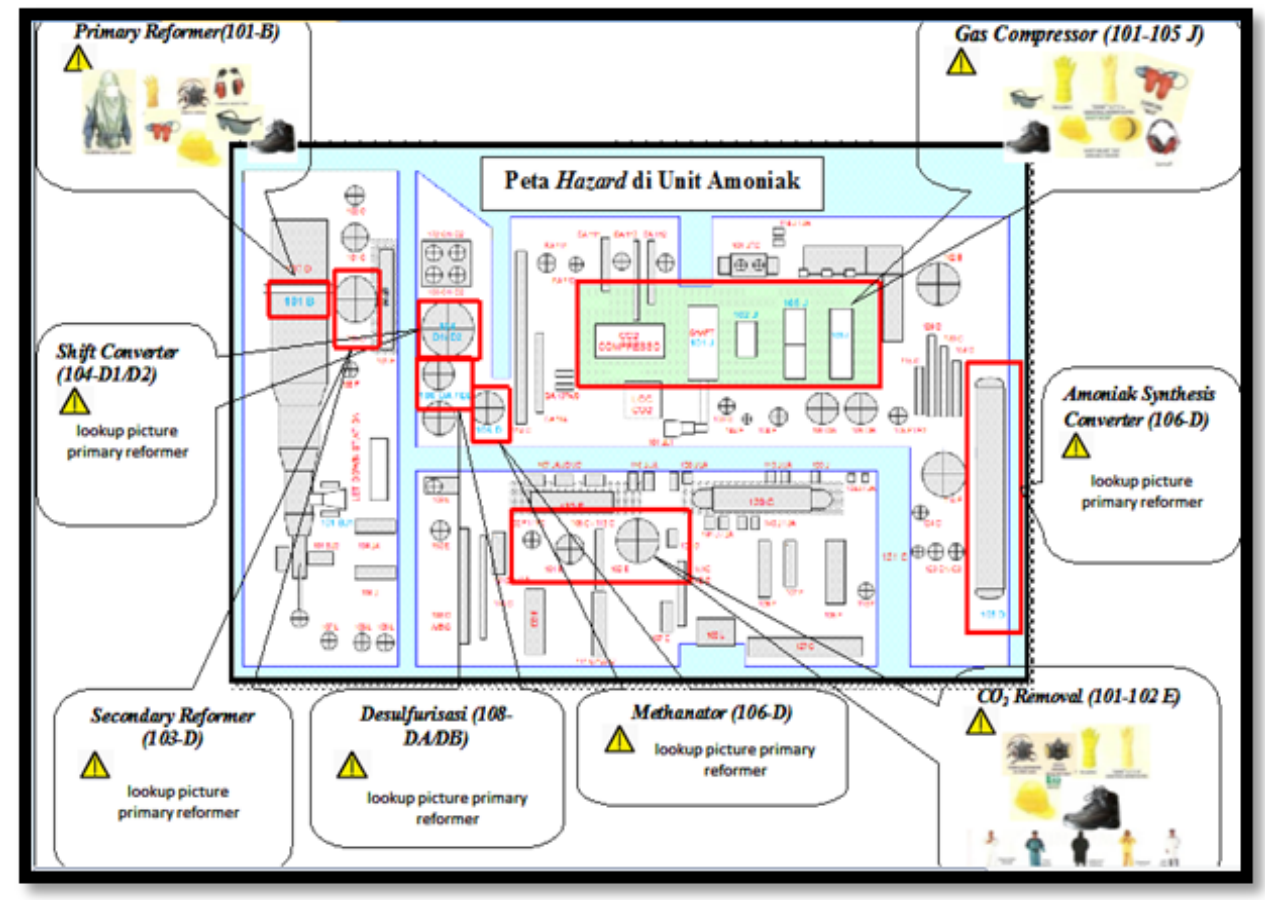

Gambar 13. Form Mapping APD

\section{KESIMPULAN}

Dari pengumpulan dan pengolahan data serta analisa yang dilakukan, didapatkan kesimpulan sebagai berikut :

1. Pada PT. Petrokimia Gresik ini diidentifikasikan ada 4 macam hazard atau bahaya yaitu bahaya fisik, bahaya kimia, bahaya mekanis dan bahaya psikologis.

2. Tindakan pencegahan dan pengendalian dari hazard yang ada telah disesuaikan dengan hirarki yaitu Eliminasi, Substitusi, Rekayasa Engineering, Pengendalian Administratif dan Alat Pelindung Diri.

3. Dari hasil risk assessment didapatkan bahwa bahaya yang memiliki nilai resiko tertinggi adalah bahaya psikologi dan bahaya fisik (kebakaran), sedangkan bahaya kebisingan serta bahaya kimia (terpapar gas/cairan Amoniak) memiliki nilai resiko tinggi juga.

4. Solusi untuk memudahkan pengidentifikasian hazard adalah dengan pembuatan Sistem Informasi Manajemen K3. Dimana dengan SIM K3 ini dimaksudkan untuk memberi pengetahuan hazard kepada pekerja dalam bentuk visual sehingga mampu melakukan pengamanan diri ketika bekerja.

\section{DAFTAR PUSTAKA}

Asfahl, Ray C. (1999). Industrial Safety and
Health Management, Fourth Edition. New Jersey : Prentice-Hall, Inc.

Chamidah, Nurul (2004). Pengukuran Tingkat Implementasi Program Keselamatan dan Kesehatan kerja (K3) dan Perangkingan Hazards dengan Pendekatan Risk Assessment di PT. Petrokimia Gresik. Laporan Tugas Akhir. Jurusan Teknik Industri ITS. Surabaya.

Larasati, A.D., 2008. Evaluasi dan Perancangan Solusi Perbaikan Sistem Manajemen Keselamatan dan Kesehatan Kerja (SMK3) dalam Upaya Perbaikan Safety Behaviour Pekerja.

Madcoms, (2008). Microsoft Access 2007 untuk Pemula. Jakarta. Andi Publisher

Nurmianto, Eko (2004) Ergonomi : Konsep dasar dan aplikasinya. Jakarta: Guna Widya.

Nurmianto Eko, Elmitha F. Wiharti, dan Naning A. Wessiani (2006) Penilaian Resiko Dan Pemilihan Alternatif Solusi Pengendalian Resiko Keselamatan Dan Kesehatan Kerja (K3) dengan pendekatan Benefit dan Cost Analysis. Seminar Nasional Ergonomi - Keselamatan \& Kesehatan Kerja, di Kampus ITS Surabaya, 29-30 Juli 2006

http://www.katigaonline.com/media/pdf/ Peraturan Perundangan Juprijadi.pdf http://www.google.com/search? client=opera\&rls $=e n \& q=$ keselamatan + keselamatan + kerja \&so 
urceid $=$ opera $\&$ ie $=u t f-8 \& o e=u t f-8$

http://fansanovahealth.blogspot.com/2009/01/ mengidentifikasi-bahava-kebakaran-dan.html http://psl.ums.ac.id/Web_Based/pdf/07-K3.pdf file://localhost/H:/KP/bahan\%20KP/alatpelindung-diri-earhearing.html

file://localhost/H:/KP/bahan\%20KP/hazardassessment.html

http://www.nationalpapercompany.com/Survei dan Perbaikan Kebocoran Udara Tekan.html

$\begin{array}{llllllllllllllll}w & w & w & . & b & a & k & o & r & m & a & s & \text {. } & c & o & m\end{array}$ pengindentifikasianresikokerjal pdf $/=$ operator $=3$

www.ini.wa.go/ipub/101-054-000.pdf 